\title{
Multidimensional Measurement of Poverty Among Employed Women in Antalya
}

\author{
Mehmet Zanbak 1 ๑
}

\begin{abstract}
The aim of this study is to identify the poverty levels of "employed women" living in 5 central districts of Antalya and are among the disadvantaged groups with a measurement method that includes social dimensions. Poverty is measured by using the Alkire-Foster (multidimensional poverty index) method rather than monetary indicators such as incomeconsumption expenditure and by taking socioeconomic indicators such as education, health, and the physical structure of the household into account. To put it another way, the multidimensional poverty approach eliminates the deficiencies of monetary poverty measures in explaining welfare. For this purpose, a field study conducted through the face-toface survey method with 400 employed and married women living in Antalya in September 2020 forms the basis for the poverty analysis. 27 indicators representing the dimensions of the socioeconomic structure, employment, income, health, empowerment, social assistance, migration, physical security, and inclusion, without feeling embarrassed, are used in order to reveal the multidimensional poverty of working women.

According to the findings of the study, income and employment are the dimensions in which women in Antalya experience the most deprivation. From this perspective, it is clear that income, particularly employment, should be prioritized in order to alleviate women's poverty in this city. For example, policies aimed at increasing women's educational attainment (positive discrimination) may make it easier for them to enter the labor market and, as a result, change their standing at work. Furthermore, expanding their economic liberties can help them enhance their socioeconomic level and gain access to better living conditions.
\end{abstract}

Keywords

Employed women's poverty, multidimensional poverty index, AF method, Antalya

\section{Introduction}

The aim of this study is to identify the factors affecting the poverty levels of employed women living in Antalya with a multidimensional analysis method other than income-based monetary approaches and present policy proposals. The main motivation to conduct the study is that mostly monetary methods are applied in poverty studies carried out in Turkey, which is believed to be inadequate in explaining social functioning and process. In this study, poverty is addressed with "the multidimensional poverty index-AF method", which is emphasized by most researchers to give better results, and it is believed that poverty will be reflected more 
realistically as a result of an analysis that prioritizes the socioeconomic and sociocultural gains of women.

The fact that a significant majority of women are disadvantaged in developing countries has directed the focus of the analysis to women. Furthermore, the fact that women's "capabilities" or "abilities" are still being questioned in all layers of society, especially in their own households, and that this leads to deprivation 1 in many areas indicates the necessity of examining women's poverty in Turkey. The empowerment of women, which can also be generalized in the form of participation in household decisions or their freedom, will reflect positively on the entire society, especially their own families, and will bring development along with it. It is of course possible and relatively simple to investigate the poverty of women, particularly those who are marginalized in the labor market and have a labor participation rate of less than $30 \%$, according to monetary indicators. However, this study examines the deprivation of women by focusing on what they have in other social dimensions besides their income, and makes suggestions to policy makers to eliminate the gaps by identifying the areas where they are disadvantaged.

The study derives its unique value from analyzing the "poverty of women" with a "new method for Turkey", which is emphasized as one of the disadvantaged groups facing discrimination and exclusion in all layers of society, labor market and households. Today, the poverty of women is measured by a multi-dimensional approach, which is a method that is increasingly used in the international institutional and academic environment. However, the fact that the subject has never been analyzed using "the method and scope discussed in this study", constitutes the main distinguishing feature of the study. In other words, the fact that a "new subject" for the national literature will be examined by a "new method" can be stated as the unique value of the study.

In addition, it is important for the originality of the study that the issue of "women's poverty", which is new for Turkey, and the method of measuring it are handled specifically in "Antalya". Antalya's role as a locomotive in the agricultural and tourism sectors causes the formation of unique structural situations in the labor market. The fact that these sectors have a high rate of unpaid family workers or low-wage employment and a female-intensive sectoral structure makes women and Antalya stand out as a unit of analysis. In other words, the discovery of the level of well-being of "women" who are disadvantaged in other social dimensions, especially with the lack of income, and the fact that no research has been conducted in the scope specified so far on the Antalya scale, can again be stated among the unique values of the study. The fact that women are subjected to gender discrimination and they are

1 The state of deprivation arises as the inability to reach or achieve any phenomenon, more precisely, the deficiency in reaching a talent (Sen, 1976). Even though deprivation, which is also defined as the inability to achieve the optimum situation that should be, varies according to the method of analysis, it corresponds to poverty if it is experienced in one or more indicators (Zanbak, 2014). 
increasingly facing physical and psychological violence both in the family and in the workplace also makes policies to address these grievances inevitable on the scale of in Antalya.

The main reason for the study to be conducted specifically for Antalya is that this city is a pioneer in two sectors, namely agriculture and tourism, and women have an important role in these sectors. In other words, determining the level of poverty of women living in Antalya, which can somehow be associated with these sectors with a labor-intensive production structure and a fairly high number of back-and-forth connections, where the women are intensively employed in the two main economic sectors mentioned above, and highlighting the factors affecting this poverty, are among the main objectives of the study. Since the feminization of poverty is generally associated with employment and the number of unpaid family workers and women working with low wages is quite high due to the sectoral structure in the region, it was deemed appropriate to conduct the analysis in Antalya. Furthermore, Antalya receives migration from all over the country, especially from the surrounding cities, and net migration has been positive for many years deu to the agriculture and tourism sectors. For instance, the fact that the population of Antalya, which exceeded 2.4 million at the end of 2018, has increased by about 600 thousand over a period of only 10 years, confirms the determination that it is a city that attracts migration. Given that nearly half of these migrating individuals are women and a significant proportion of them are mothers/wives, the level of women's well-being becomes even more important. In this regard, the study also aims to reveal the reflections of migration to Antalya as a regional center of attraction on women's poverty.

In this context, the main hypotheses of the study are:

- Women's poverty is a multidimensional concept.

- Women's poverty is affected by socioeconomic and sociocultural factors, as well as personal and household income.

- Differentiation of districts where women live changes the multidimensional poverty rate (index).

The aim of the study is to make recommendations to policymakers in order to eliminate the prominent problems that stand out based on the findings, prevent women from being subjected to discrimination, injustice and violence, not to continue their lives dependent on others. In line with these goals and objectives, a field study consisting of 132 questions was conducted through the face-to-face survey method with 400 employed and married women living in 5 central districts (Döşemealtı, Kepez, Muratpaşa, Konyaaltı, Serik) of Antalya in September 2020 in order to measure the poverty of women in a multi-dimensional way. In this survey, personal information and the socioeconomic structure of the household constitute the first dimension, while other topics such as employment, income, health, empowerment, 
social assistance, migration, physical safety, and inclusion without feeling embarrassed can be listed as the other dimensions. One of the points aimed to be revealed in the study is the relationship between women and their spouses and/or the place of employment and whether they are exposed to domestic violence or mobbing. Therefore, in the study, the fact that married and employed women are chosen, reflects a situation towards obtaining findings related to the dimension of empowerment.

Accordingly, the conceptual framework of women's poverty constitutes the first part of the study, followed by the multidimensional poverty measurement method. In the third part of the study, the literature on women's poverty is summarized briefly and in the fourth part, women's poverty in Antalya is analyzed. The study's results section includes policy recommendations based on the findings.

\section{Women's Poverty: The Conceptual Framework}

Amartya Sen, one of the first scientists to come to mind in the field of development economics, addressed poverty in the mid-70s from the perspective of ability/capacity/capability ${ }^{2}$, and during the same period, Peter Townsend evaluated this situation as a lack of resources (Sen, 1976: 221; Townsend, 1979: 914). Both perspectives continued with the assessment of poverty as a state of deprivation of physical and human needs such as nutrition, clothing, housing, health, education in addition to income. In other words, it is widely accepted that level of income, job opportunities, income distribution, leisure time, education and health opportunities, work opportunities, political independence, good governance, and gender and ethnic equality are all linked to life satisfaction and happiness (Kartal \& Zanbak, 2020). Human development, which can also be considered as the development of human abilities, includes happiness, being able to do anything freely, the expansion of freedoms and the multiple expectations of life (Krueger \& Schkade, 2008). After determining that the conceptual framework of poverty does not depend solely on income, the concept of deprivation has also come to the fore, and the researchers began to focus on the lost dimensions of poverty, namely deprivation (Zanbak, 2014).

Both income-based and skill-driven analyses show that the devastating effects of poverty are not reflected in all segments to the same extent. In other words, it can be said that women, together with children, the elderly, and the disabled, constitute the most disadvantaged group affected by poverty. In addition, the reports of the United Nations show that women constitute $70 \%$ of the individuals (approximately 1.5 billion) identified as poor worldwide (UNDP, 1995). It can also be noted that the concept of feminization of poverty was first used by Pearce (1978), who preferred this concept to emphasize that nearly $70 \%$ of the poor in America

2 It is used to describe an individual's ability to receive various combinations of services such as housing, nutrition and education (Sen, 1999). 
are women, and their economic and social development rates are slow, even though women are increasingly taking part in the labor market (Pearce, 1978: 28-36). The point reached requires the definition of the concept of "feminization of poverty" and the creation of specific policies for this disadvantaged group. In the Fourth World Conferences on Women, the concept of women's poverty came to the fore and attention was drawn to policies and strategies for women's empowerment (Şener, 2012: 54; Topgül, 2013: 289, Gerşil, 2015: 162). It was emphasized at this conference that women are more likely to remain poor, and that poverty violence is on the rise (Ecevit, 2003: 85; Bayır, 2018: 33; Kartal \& Zanbak, 2020: 296). In addition, Arpaci (2010: 6) mentioned that women's poverty differs according to time and place (region), and Moghadam (2005) pointed out the facts that women are more involved in the household and bear a greater economic burden, and marginalizing attitudes towards women in the household/region and socioeconomic restrictions/exclusion are among the factors that cause poverty (Moghadam, 2005: 1).

Goldberg \& Kremen (1990: 6-7) and Peterson (1987: 330) noted that women felt poverty more severe due to their position in the labor market (mostly part-time employment), their black skin, relatively lower hourly wages and exposure to sexist discrimination. On the other hand, the researchers noted that prioritizing men in improvements in employment and social policies, shortcomings in transfer spending, changes in marital status (especially divorce or spouse's death) and the number of children (especially single motherhood) also drive women into poverty. The responsibilities imposed on women, especially in childcare, and their absence from decision-making mechanisms within or outside the household also negatively affect women in terms of poverty (Wilson, 1987: 21). According to another researcher, Buvinic (1997; cited in Büyükyörük, 2019: 35-36), there are two fundamental reasons that affect women's poverty, the first of which is that women are in a secondary position in the labor market and they have to work in labor-intensive jobs for low wages, and the second is that they are uneducated compared to men due to their limited/limited access to education, and therefore they are willing to work in informal sectors.

Based on the studies discussed, it can be said that the level of education and the position in the labor market are among the reasons that lead to women's poverty. In addition to this, the fact that the heads of the households are women and the marital status of these women, the number of children and their income levels can also be listed among the factors affecting the poverty of women and therefore the households.

\section{Multidimensional Poverty Approach}

Until recently, poverty has been analyzed with monetary indicators, especially under the leadership of international organizations and in the academic community, and in the light of the findings reached, conclusions have been made primarily for income or consumption. In other words, while the measurement method is preferred by determining an income or 
consumption expenditure level, which is also known as the poverty line, individuals below the line are identified as poor. However, developments in development economics have also changed the perspective on poverty, which has resulted in the stretch/diversification of the methods of addressing poverty. This development can be clearly seen in the 1995 World Development Report of the United Nations and the Millennium Development Goals determined by the World Bank in 2000 (UNDP, 1995; World Bank, 2000). In the following period, the "Alkire and Foster (AF) Approach" (2011a; 2011b), which was based on the FGT method developed by Foster, Greer, and Thorbecke (Foster et al., 1984), noted that the social dimensions of poverty should also be taken into consideration and noted that the problem of poverty should be purged from the general acceptance of the individual's lack of a minimum income level in order to maintain only his biological existence. In this approach, it is emphasized that in addition to household or individual income, dimensions such as education, employment, empowerment, sociality, security also affect individual well-being (Zanbak, 2014).

In this study, which addresses multidimensional women's poverty, the measurement is based on the AF approach and methods related to this approach are applied.

\section{Multidimensional Poverty Measurement Method}

The main stages of the method used to make a multidimensional poverty measurement based on the AF approach can be shown as in the flow diagram in Figure 1 (Zanbak \& Çağatay, 2013, Zanbak, 2014). This flow diagram can also be presented algebraically and numerically (Alkire \& Foster, 2011a; 2011b; Alkire \& Santos, 2014; Alkire \& Seth, 2013; Foster, 2007).

It is important to determine the appropriate dimension and the indicators that will represent them at the beginning of the calculation phase of the index. In this study, the said dimension and the number of indicators were determined as 9 and 27, respectively. While determining each indicator's own deprivation limit is crucial to understand whether the individual is lacking in that indicator, this step is perhaps the turning point of the measurement. Because it is very important to determine the poverty and deprivation limits accurately in order to be able to decide on the poverty of the individual in poverty measurements. The Alkire-Foster (AF) method, which makes counting-based measurement, uses a method of determining poverty, known as the "dual-cutoff method", in which the boundaries of poverty and poverty can be determined effectively, dividing the sample into subgroups and showing the depth, severity and even the intensity of poverty. Therefore, it is also possible to state that the AF method makes measurements with the help of matrices. In this counting-based method, first matrices are defined, then multidimensional poverty and related multidimensional poverty indices are calculated using the censored matrix. At this point, the stages of obtaining the index can be mathematically expressed as follows in order to make it easier to understand the expression (Alkire \& Foster, 2011 a; 2011b; Zanbak, 2014; Kartal \& Zanbak, 2020). 


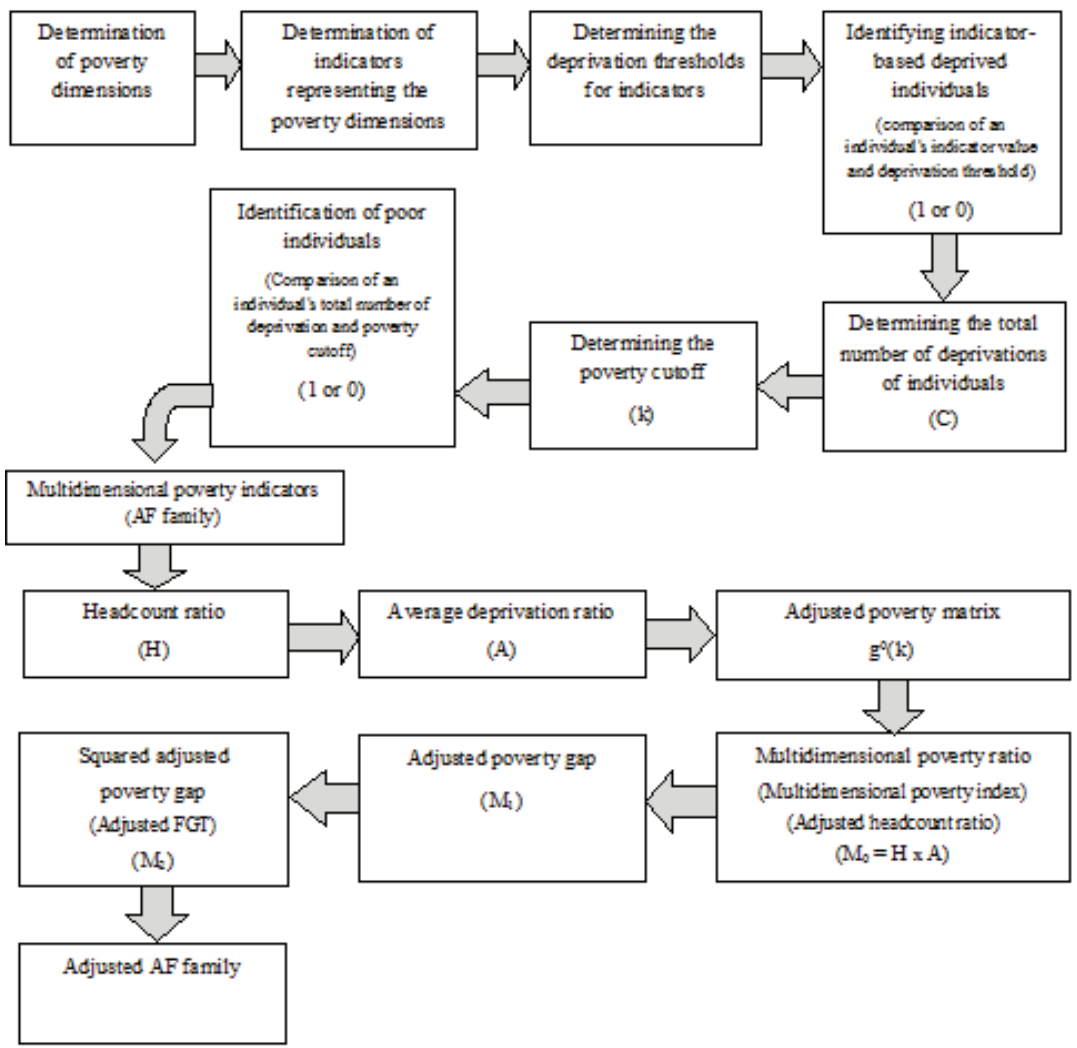

Figure 1. The Stages of Obtaining Multidimensional Poverty Index by the AF Method Source: Zanbak \& Çağatay, 2013; Zanbak, 2014.

First, the matrix, which is called the objectives-outcomes connectivity matrix and expressed as $\mathrm{A}=\left[\mathrm{A}_{\mathrm{ij}}\right]_{\mathrm{nxd}}$, consisting of $n$ observations (individuals) and $d$ dimensions/indicators with $n \mathrm{x} d$-dimensional raw data is defined (Equation 1$)$. In this $\left(\left[\mathrm{A}_{\mathrm{ij}}\right]_{\mathrm{nxd}}\right)$ matrix, the columns represent the dimensions and the sub-indicators of the dimensions, if any, while the rows reflect the values each individual takes in the dimension/indicator. For example, the point at which the first row and the first column intersect (the value expressed as $a_{11}$ in Equation 1) shows the value of the first observation in the first dimension/indicator.

$$
\begin{gathered}
\text { Dimension (Indicator) } \\
A=\left[\begin{array}{ccccc}
a_{11} & a_{12} & a_{13} & \ldots & a_{1 j} \\
a_{21} & a_{22} & a_{23} & \ldots & a_{2 j} \\
a_{31} & a_{32} & a_{33} & \ldots & a_{3 j} \\
a_{41} & a_{42} & a_{43} & \ldots & a_{4 j} \\
\ldots & \ldots & \ldots & \ldots & \ldots \\
a_{i 1} & a_{i 2} & a_{i 3} & \ldots & a_{i j}
\end{array}\right] \text { Individual }
\end{gathered}
$$


In the second step, the deprivation limit vector matrix $(Z)$ is defined.

$$
\mathrm{Z}=\left[\begin{array}{lllll}
Z_{11} & Z_{12} & Z_{13} & \ldots & Z_{1 j}
\end{array}\right]
$$

The matrix expressed in Equation 2 is a $1 \mathrm{x} d$-dimensional matrix. The value of each dimension and sub-indicator determined by the researcher is compared with the values of the dimension/sub-indicator to which it belongs. Individuals with values less than (or greater than) these are considered deprived in that dimension/indicator, and 1 is written in the corresponding place in the matrix created in the next stage. This is an important indicator in determining which individual is deprived of what dimension/indicator, and 0 is written to the corresponding matrix if the individual is not deprived of that dimension/indicator.

In the third step, the matrix of deprivation numbers is defined.

$$
\mathrm{C}=\left[\begin{array}{lllll}
\mathrm{C}_{11} & \mathrm{C}_{21} & \mathrm{C}_{31} & \ldots & \mathrm{C}_{\mathrm{i} 1}
\end{array}\right]^{\prime}
$$

It is a $n x 1$ dimensional matrix shown in Equation 3, and it should be noted that the equation in the present representation is the transposition of what should be. The dimensions/ indicators in which each individual is considered deprived are counted, the number of these deprived dimensions/indicators is summed and the sum is written into this matrix. In this way, the number of dimensions/indicators in which each individual is deprived in total is revealed. It can also be emphasized that Equation 3 is an important indicator in terms of reflecting the depth of the deprivation of individuals.

The poverty line must be defined in the next step of calculating the index. This value, expressed as $k$, must be greater than zero and smaller than the total number of dimensions (indicator in some studies) used in the study $(0<k<\mathrm{d})$. If the number of dimensions in which the individual experiences deprivation in matrix $C$ in Equation 3 is equal to or greater than the value of $k$ (the poverty line), this individual is considered poor. This determination is very important in terms of showing how many individuals remain below the $k$ threshold value in the observation group and therefore how many poor people are in the sample. After the identification of poor individuals, a censored deprivation matrix should be created, which is also necessary to determine how many poor individuals there are in total within the observation group covered in this matrix.

\section{Multidimensional Poverty Indices}

The multidimensional poverty indices can be listed as the headcount ratio $(\mathrm{H})$, the average deprivation rate $(A)$ and the adjusted headcount ratio $\left(\mathrm{M}_{0}\right)$. In addition, it is possible to reach the adjusted poverty gap $\left(\mathrm{M}_{1}\right)$ and adjusted squared poverty gap $\left(\mathrm{M}_{2}\right)$ index values, but the measurement of these indices is excluded from the scope of this study. 


\section{Headcount Ratio (H)}

In the $\mathrm{AF}$ approach, the calculation of headcount ratio $(\mathrm{H})$ (Equation 4) is the first step to be taken after the creation of the necessary matrices to obtain the multidimensional poverty index and identifying the poor individuals (Alkire \& Foster 2011b). In this ratio, which is given in Equation 4, $\mathrm{n}$ represents the sample size, and q represents the number of individuals identified as "poor" at the specified poverty line. This value, which can also be expressed as the ratio of poor people in the focused sample group, is between 0-1. Even though at first glance it makes it possible to compare the poverty of different samples, the inability to provide information about the depth of the poverty experienced causes discussions about the adequacy of this ratio. Because Alkire and Foster (2011b) emphasized that this ratio alone is not sufficient to reflect the exact position of whether the poor individual remains below the poverty line or non-poor individual remains above the poverty line. Furthermore, the fact that there is no change in the said ratio if poor individuals become even poorer and that this ratio cannot reflect the development experienced is another issue of criticism. Therefore, another value, the average deprivation rate $(\mathrm{A})$, is needed to measure the multidimensional poverty index.

\section{Average Deprivation Rate (A)}

This ratio (calculation method is shown in Equation 5) reflects the severity of the deprivation and eliminates the above-mentioned problem that the headcount ratio alone is not sufficient in terms of identifying the exact situation of the people in deprivation. The average deprivation rate, also expressed as deprivation per dimension, is between $0-1$, where 0 means no deprivation per dimension, and 1 corresponds to the deprivation of poor individuals in all dimensions. In the calculation of this ratio, which is also shown in Equation 5, c represents the total of deprivations, q represents the number of poor individuals, and $\mathrm{d}$ represents the dimension and/or the number of indicators, although it varies according to the study.

\section{Adjusted Headcount Ratio ( $\left.\mathbf{M}_{\mathbf{0}}\right)$}

The adjusted headcount ratio $\left(\mathrm{M}_{0}\right)$, obtained as a result of evaluating the ratio of the number of poor people together with the deprivation rate per dimension, is also called the multidimensional poverty index (Alkire \& Foster, 2011a). As shown in Equation 6, this ratio, which is obtained from the product of the headcount ratio $(\mathrm{H})$ and the average deprivation rate (A), is important in determining the severity of poverty and is expressed as the average of the censored poverty matrix (where all the values of non-poor individuals are updated to 0 ). In other words, the increase of this value (approaching 1) between units or times corresponds to an increase in poverty and sheds light on policy makers.

$$
\begin{aligned}
& H=\frac{q}{n}(4) \quad A=\frac{\text { average deprivation }}{\text { number of indicators }}=\frac{\frac{\text { total deprivation }}{\text { number of poor people }}}{\text { number of indicators }}=\frac{\left(\frac{c_{1}+c_{n}}{q}\right)}{d}=\frac{\frac{\sum_{1}^{d} c_{i}}{q}}{d} \\
& M_{0}=H \times A(6)
\end{aligned}
$$




\section{Summary of Literature on Women's Poverty}

The literature discussed in this study is divided into two parts. The first part focuses on monetary approaches based on income and consumption expenditures, whereas the second part focuses on a multidimensional approach that includes social indicators rather than monetary indicators. While poverty is measured with a multidimensional method in this study, which aims to reveal the poverty of working women in Antalya, it differs from income-based studies, which account for a substantial portion of the national literature. However, it should be noted that women's poverty has yet to be measured in Turkey using the AF approach, and this study is unique in this regard.

A significant portion of the "women's poverty" studies in the literature approach poverty with monetary indicators, some of which can be listed as studies conducted by Şener (2012), Açıkgöz (2010), TEPAV (2009), Kardam \& Yüksel (2004), Buvinic (1997), and Moghadam (2005). Addressing the issue within the framework of the "feminization of poverty", Sener (2012) emphasized that poverty is mostly associated with women's employment status, and noted that the main factor that causes poverty is the low labor force participation rate, which is close to $30 \%$. In the study, which shows that the non-agricultural unemployment rate of women is about $18 \%$, it is also determined that the share of unpaid family workers in total employment is about $15 \%$. According to the researcher, this naturally leads to female poverty. Açıkgöz (2010) showed the facts such as divorce, family disintegration, male unemployment, wars and internal conflicts are among the main factors affecting the poverty of women in Turkey. From that perspective Açıkgöz defined the concept of feminization of poverty as the fact that women who have to support their households make up the majority among all the poorconstitute the majority of the poor. In addition, the researcher stated that gender inequalities are common in Turkey and gender-based division of labor and women's work in unpaid jobs pushes them into economic and social insecurity, which leads to the natural impoverishment of women.

Similarly, Duyan Çamur (2010) listed the factors that cause poverty as women being deprived of income, the fact that poverty being passed down through the family, the conditions of the house they came to as a bride are same as the conditions of their family before they got married, and both of them are poor and they are unable to leave their spouses. Yalçın (2018) noted that inequalities in the household, insufficient education, divorces as a result of wrong marriages, low wage employment of women, being the head of the household, and working as an unpaid family worker in rural areas are the main factors affecting female poverty. Şahin \& Şahin (2018) stated that women's poverty is a problem that can be solved in the long term, and pointed out that government policies should be improved and the capacities of institutions serving in this field should be increased to overcome this problem. TEPAV (2009), which approaches women's poverty with an income-based approach 
as well as a/the capability method, stated that although women earn high incomes and do not experience income deprivation, they spend more time on household chores than men, especially those who are engaged in childcare for longer periods of time and ultimately face “time deprivation". Similarly, Kardam \& Yüksel (2004) also discussed women's poverty from the point of view of capability, and evaluated the differences in capabilities of women who are similar to each other financially as a result of face-to-face interviews with 40 lowincome women in Ankara. Although differences are seen and improvements are required in issues such as employment, education and health, it has been stated that the first policy that should be applied to women is to protect their physical integrity, ensure their safety and prevent violence against women.

Considering the international literature, there are many studies focusing on women's poverty by methods including social dimensions, some of which are Moghadam (2005), Buvinic (1997), Bastos, Casaca, Nunes, \& Pereirinha (2009), Batana (2013), Wu \& QI (2017) and Maduekwe (2018). According to Moghadam (2005) and Buvinic (1997), the main factors that cause feminization of poverty are the position of women in the labor market and the degree to which they benefit from educational opportunities. Although they earn a certain amount of income, discrimination, household inequalities, low wage level, being the head of household are pointed out as negative reflections on poverty. On the other hand, Bastos et al. (2009) highlights that older women, women living alone, and households with women as the head of the family suffer from fairly high levels of income poverty. In addition, the researchers drew attention to the fact that women are exposed to discrimination in the labor market and other gender-based cases, and the point reached is driving women into poverty. Similarly, Batana (2013) conducted a study using the AF method and highlighted the importance of education in women's poverty. Wu \& QI (2017) emphasized gender inequality and drew conclusions about the dilemma of access to opportunities such as education and health, especially in rural areas. A multi-dimensional approach was preferred for identifying the poor in Maduekwe's (2018) study, and it was emphasized that the key factor affecting women's poverty in Malawi, a Sub-Saharan African region, is their exclusion from decision-making mechanisms. To put it another way, a significant majority of women in this country are deprived in the dimension of empowerment. According to the researcher, the fact that women in this region cannot decide freely about their individual health increases their poverty by $80 \%$.

\section{Multidimensional Measurement of Employed Women's Poverty in Antalya}

In this section, an $\mathrm{AF}$ approach-based analysis is carried out to examine the poverty of employed women living in Antalya, and based on the findings obtained, policy recommendations are presented to reduce the poverty of women living in this city. 


\section{Field Study-Obtaining the Primary Database}

The study area was composed of 5 districts of Antalya (Döşemealt1, Kepez, Muratpaşa, Konyaalt1, Serik), while the target group was determined as the female population ${ }^{3}$, which is around 840 thousand in Antalya as of 2018, aged between 15+ and 65- (TurkStat, 2019). If the population is specific, but the variance is not specific, the sample size to represent this is found by the formula given in Equation 7-8. At this point, Equation 7-8 and Equation 9-10 can be applied as the population is greater than 10,000 .

$$
n=\frac{N \cdot P \cdot Q \cdot Z_{\propto}^{2}}{(N-1) \cdot d^{2}}(7) \quad n=\frac{N \cdot P \cdot Q \cdot t_{\alpha s d}^{2}}{(N-1) \cdot d^{2}}(8) \quad n=\frac{\sigma^{2} \cdot Z_{\propto}^{2}}{d^{2}}(9) \quad n=\frac{P \cdot Q \cdot Z_{\propto}^{2}}{d^{2}}
$$

Where; N: Population size; n: Sample size; P: The rate of observing X in the population; $\mathrm{Q}$ (1-P): the rate absence of $\mathrm{X} ; \mathrm{Z}_{\mathrm{a}}: 1.96,2.58$ and 3.28 , respectively for $\mathrm{a}=0.05,0.01,0.001$ values; $d=$ Sampling error; $s=$ Population standard deviation; $t_{a, s d}=t$ distribution values with sd degree of freedom $(\mathrm{sd}=\mathrm{n}-1)$. $\mathrm{t}_{\mathrm{a}, \mathrm{sd}}$ values can be taken equal to $\mathrm{Z}_{\mathrm{a}}$ values when $\mathrm{sd}=\mathrm{n}-1 \rightarrow$. When using this method, the ideal number of observations is obtained around 400 and statistical representation can be achieved with this number. The sample group was randomly selected from a distribution applied by the Turkish Association of Researchers that placed the provinces into sub-regional definitions A, B, C, D and E according to their socioeconomic levels (TÜAD, 2012). As mentioned, the sample included 5 districts, and 80 working women were interviewed in each district in order to make a comparison between these districts.

The survey applied consists of 10 titles and 9 dimensions. These can be listed as personal information and socioeconomic structure of the household, employment, income, health, empowerment, social assistance, migration, physical safety and inclusion without feeling embarrassed. A total of 132 questions were asked to women about these dimensions, and the answers given to these questions formed the basis for urban and district-based calculation of poverty rates.

\section{Descriptive Statistics}

It is possible to present descriptive statistics of the sample of women living in Antalya based on the field study data applied to randomly selected 400 working and married women (Table 1). In this way, the underlying factors of women's poverty and the possible causes will be determined.

Considering the data set obtained, it is seen that approximately $40 \%$ of the women in the sample are primary school graduates and 36\% are high school graduates, which shows that only 1 out of every 4 women received a university education. A significant majority of

3 In the study, the women interviewed were required to be "married" and "employed" in order to reflect the position/ situation of them, especially in the labor market and in the household. In other words, the sample of the study consists of employed/married women aged between 15 and 65 . 
women (75.8\%) with an average age of 39 are between the ages of 25-49. On the other hand, the number of women who do not have children is 66 , while women with 2 or more children constitute approximately $60 \%$ of the total.

When asked about the ownership status of the residence, $56.5 \%$ of the women answered that they are living in a rental house. The rate of those who stated that they live in their own house was around $41 \%$, and 8 women stated that they reside in a house that belongs to their relatives (mother/father/mother-in-law/father-in-law) without paying any rent. In addition, out of the number of individuals working in the household, 7 women in the sample provide for the house alone. Considering that the women included in the survey were required to be employed/married, 7 households with 1 employee support this finding. In addition, the rate of women who stated that other members of the household other than their children or spouses also work is around $8.5 \%$, which means that the number of income-generating members is 3 or more in 33 out of 400 households. Considering the status of working women at their workplaces, it is seen that the paid working class stands out with a $60 \%$ share, while the ratio of those who say that they are involved in the economy as employers is around $25 \%$. In other words, only 1 out of every 4 women in the sample is in an employer position. However, a detailed examination of the survey shows that 186 out of 400 women earn an income below the minimum wage and 214 of them do not have a formal employment contract with their workplaces. These numbers show that a significant majority of the working class cannot receive even the minimum wage, and they are trying to gain income under difficult conditions in the labor market, mainly in the agriculture-tourism sectors. Furthermore, $75 \%$ of women live in debt, while about $70 \%$ of them do not have any savings. This seems to be consistent with the response of 4 out of every 5 women that they have more or less financial difficulties. It can also be emphasized that $26.8 \%$ of the women in Antalya, the vast majority of whom stated that they had difficulty making a living, also suffer from health problems.

One of the interesting results obtained in regard to the sample is related to the household income, where the lowest income is 1,500 TL, while the highest income is 80,000 TL. However, the average household income is just above 7,000 TL. Given that there are quite a high number of women who report having difficulties in making a living, and the average income is around 7,000 TL, it can be said that women (or their households) who do not have financial difficulties earn quite a high income, which indicates that the income distribution among the women in the sample is concentrated at two different ends. In particular, the high-rate of reports (approximately 72\%) regarding the need for social assistance are consistent with responses (about 80\%) that women in the lower income group (hence their households) are struggling to make a living. Of the 400 women surveyed in the field study, 214 responded that they settled in Antalya through migration, and approximately half of these women carried out this action over a period of 10 years. However, their migration to Antalya, which they attribute to economic reasons, only strengthened the economy of $46 \%$ 
of households. In other words, the rate of women who stated that their economic situation deteriorated after emigrating was $12.6 \%$, while the rate of those who stated that there was no change was over $40 \%$.

18 of the women participating in the survey have been subjected to physical violence in the last 5 years, 11 of whom have encountered the incident at home. On the other hand, approximately $17 \%$ of women who said that they were subjected to violence during the same period experienced this victimization at school. When it comes to the question of who is the head of the household, which reflects the position of women in the household, the number of women who stated that they are the head of the household is only 54, and this result corresponds to a small minority of the sample. This result, which can also affect the participation and therefore empowerment of women in decisions about themselves or their family (household), reveals the male-dominated family structure in Antalya. However, the number of women stating that they are on top of the ranking, created to reflect whether a woman feels free or not, and where the top ranking ( $6^{\text {th }}$ step) represents complete freedom, is 144. This is a different indicator showing that the remaining 256 women do not feel completely free, albeit at different levels, and may have to get approval in their decisions. Finally, in the light of the findings obtained from the survey, it can be emphasized that half of the women who were analyzed for poverty wanted to make changes in their lives. Considering that approximately $75 \%$ of these women live in debt without any savings and 4 out of every 5 of them had financial difficulties, it is quite surprising that only $50 \%$ of them want to make changes in their lives. This result reflects the fact that, despite their difficulties in earning a living, a significant number of women agreed to this and do not want to change their current situation.

\section{Dimensions, Indicators, and Deprivation Conditions Used in the Study}

As previously stated, the AF method was used in this study to reveal the level of women's poverty and which indicators the deprivation is concentrated/deepened. Alkire and Foster (2011a) focused on 3 dimensions and 10 indicators when measuring poverty with this method and made an analysis based on these indicators. In order to represent the dimensions of living standards, education and health, assets consisting of household appliances/machines, fuel used in the kitchen, floor of the house, clean water, electricity, nutrition, death, school attendance year and school education period were discussed. In this way, each dimension and indicator used in the study are weighted equally. 
Table 1

Descriptive Statistics of Employed Women Living in Antalya and Their Households

\begin{tabular}{|c|c|c|c|c|c|c|c|}
\hline & & Individual & $\%$ & & & Individual & $\%$ \\
\hline \multirow{4}{*}{ Education } & Primary School & 160 & 40.0 & \multirow{3}{*}{ Health Status } & Poor & 7 & 1.8 \\
\hline & High School & 145 & 36.3 & & Moderate & 100 & 25.0 \\
\hline & University & 86 & 21.5 & & Healthy & 293 & 73.3 \\
\hline & $\begin{array}{l}\text { Graduate } \\
\text { School }\end{array}$ & 9 & 2.3 & \multirow{3}{*}{$\begin{array}{l}\text { Household } \\
\text { Income } \\
\text { (TL) }\end{array}$} & Lowest & 1.500 & - \\
\hline \multirow{4}{*}{ Age } & Average Age & 39 & - & & Highest & 80.000 & - \\
\hline & $15-24$ & 38 & 9.5 & & Average & 7.069 & - \\
\hline & $25-49$ & 303 & 75.8 & \multirow{6}{*}{$\begin{array}{l}\text { Feel of Finan- } \\
\text { cial Difficulties }\end{array}$} & Never & 84 & 21.0 \\
\hline & $50+$ & 59 & 14.8 & & So Lightly & 69 & 17.3 \\
\hline \multirow{5}{*}{$\begin{array}{l}\text { Number of } \\
\text { Children }\end{array}$} & No child & 66 & 16.5 & & Lightly & 81 & 20.3 \\
\hline & 1 & 105 & 26.3 & & Moderate & 111 & 27.8 \\
\hline & 2 & 164 & 41.0 & & Severe & 47 & 11.8 \\
\hline & 3 & 49 & 12.3 & & Very Severe & 8 & 2.0 \\
\hline & 4 and more & 16 & 4.0 & \multirow{2}{*}{$\begin{array}{l}\text { Social Need of } \\
\text { the Household }\end{array}$} & Yes & 113 & 28.3 \\
\hline \multirow{5}{*}{$\begin{array}{l}\text { Status of the } \\
\text { Residence }\end{array}$} & Own Hose & 165 & 41.3 & & No & 287 & 71.8 \\
\hline & Rental & 226 & 56.5 & \multirow{4}{*}{$\begin{array}{l}\text { Time Spent in } \\
\text { Antalya After } \\
\text { Migration }\end{array}$} & $\begin{array}{l}\text { Less than } 1 \\
\text { Year }\end{array}$ & 2 & 0.9 \\
\hline & Public Housing & 1 & 0.3 & & 1-5 Years & 62 & 29.0 \\
\hline & & & & & 6-10 Years & 49 & 22.9 \\
\hline & rent & 8 & 2.0 & & $\begin{array}{l}\text { More than } 10 \\
\text { Years }\end{array}$ & 101 & 47.2 \\
\hline \multirow{5}{*}{$\begin{array}{l}\text { Number of } \\
\text { Individuals } \\
\text { Employed }\end{array}$} & 1 & 7 & 1.8 & \multirow{3}{*}{$\begin{array}{l}\text { Financial Si- } \\
\text { tuation after } \\
\text { Migration }\end{array}$} & Improved & 99 & 46.3 \\
\hline & 2 & 360 & 90.0 & & Worsened & 27 & 12.6 \\
\hline & 3 & 26 & 6.5 & & $\begin{array}{l}\text { Didn't Chan- } \\
\text { ge }\end{array}$ & 88 & 41.1 \\
\hline & 4 & 6 & 1.5 & \multirow{4}{*}{$\begin{array}{l}\text { The Place of } \\
\text { the Violence } \\
\text { Experienced }\end{array}$} & House & 11 & 61.1 \\
\hline & 5 & 1 & 0.3 & & School/Work & 3 & 16.7 \\
\hline \multirow{5}{*}{$\begin{array}{l}\text { Position in } \\
\text { the Work- } \\
\text { place }\end{array}$} & Employer & 98 & 24.5 & & In Public & 1 & 5.6 \\
\hline & Paid Worker & 240 & 60.0 & & Other & 3 & 16.7 \\
\hline & Officer & 14 & 3.5 & \multirow{4}{*}{$\begin{array}{l}\text { Head of the } \\
\text { Household }\end{array}$} & Partner & 343 & 85.8 \\
\hline & Jobber & 4 & 1.0 & & Herself & 54 & 13.5 \\
\hline & $\begin{array}{l}\text { At Own Ex- } \\
\text { pense }\end{array}$ & 44 & 11.0 & & Father & 2 & 0.5 \\
\hline \multirow{2}{*}{ Debt } & Yes & 297 & 74.2 & & Mother & 1 & 0.3 \\
\hline & None & 103 & 25.8 & \multirow{3}{*}{$\begin{array}{l}\text { Willingness to } \\
\text { Make Changes } \\
\text { in Life }\end{array}$} & Yes & 198 & 49.5 \\
\hline \multirow{2}{*}{ Savings } & Yes & 121 & 30.2 & & None & 202 & 51.5 \\
\hline & None & 279 & 69.8 & & & & \\
\hline
\end{tabular}

In this study focusing on women's poverty in Antalya, a poverty measurement is carried out with 9 dimensions in which there are 3 indicators in all dimensions and therefore 27 indicators. The first dimension is "information about the socioeconomic structure of the person and the household", which is represented by the indicators of "white appliances, computers and the internet". Women who do not have a washing machine and dishwasher, their own computer and internet access at the same time are considered to be deprived of these indicators. In the indicators of "employment contract, daily working hours and psychological and 
physical pressure" of the "employment" dimension used in the measurement, women who do not have an official employment contract with the employer, whose daily working hours are over 8 hours and who are subjected to psychological or physical pressure in the working environment are included in the deprivation matrix. In addition to these, another dimension focused on is the "net wage, debt and savings" indicators in the "income dimension". Individuals whose wages are below the current minimum wage in 2020 are considered to be deprived in the net wage indicator. On the other hand, a woman who is in debt and does not have any savings is considered to be deprived in the aforementioned indicators. Another dimension included in the calculation in poverty measurement is "health", which is represented by the indicators of "health status, number of illnesses and effects of health problems". Women who stated that they were not in good health, that they had at least 1 chronic illness and that their health problems negatively affected their daily lives were considered deprived. The "empowerment" dimension, which is among the most important dimensions included in the study, whose results arouse curiosity and reflects whether the woman is externally dependent on making decisions about herself or her family, is represented by the indicators of "personal decision control, possible reasons for inability to work in the future, feeling free". If a woman does not feel strong in controlling her personal decisions or feels pressure to quit her job against her will in the future, she is included in the measurement as deprived in these indicators. However, if she has responded 3 or below, which is a half-step on the 6-step dependency/ freedom ladder, this woman is considered to be deprived of the feeling free indicator. The sixth dimension of the study, "social assistance", is included in the measurement based on the indicators of "financial difficulties, need for social assistance and receiving social assistan$c e$ ". Women who reported that they had financial difficulties, needed social assistance, and had to get institutional or individual assistance due to financial difficulties were considered to be deprived in these indicators.

"Migration", which is another dimension focused on in the study, is represented by the indicators of "migration, change in living conditions as a result of migration, thinking about migration in the future". The women who were forced to migrate at least once in their life, whose living conditions did not change with the migration or whose situation worsened compared to their previous situation and who were considering migration from Antalya in the future were considered to be deprived in the study. In addition, the "physical safety" dimension is perhaps the most important dimension in terms of reflecting whether the environment in which women live is safe and whether they are/will be exposed to violence or not. This dimension included in the measurement is represented by the indicators of "theft, physical violence/injury and the possibility of being exposed to violence within 1 year". The women who have experienced theft in their households in the past, who have been subjected to violence (firearms or beating) against themselves or one of their family members in the past 5 years, and who reported that they will be victims of violence in the next 12 months, even 
with a low probability, are considered to be deprived in these indicators. The last dimension in the multidimensional measurement of women's poverty is the dimension of "inclusion without feeling embarrassed" in the society, which is represented by the indicators of "being embarrassed due to being poor, being treated with prejudice and feeling excluded". The women who reported that they would be ashamed of their poverty or if they were poor, that they had been treated with prejudice in the last 3 months and felt excluded from the society were included in the study as deprived.

\section{Multidimensional Poverty Index Values of Employed Women in Antalya}

In this study, employed women's poverty is measured by calculating the $\mathrm{M}_{0}$ value by using the data obtained from the field study conducted in Antalya. For this purpose, the steps presented in Figure 1 were followed respectively and the index values (Equation 4-5-6) were obtained.

In this survey, the multidimensional poverty index was calculated using personal information and the socioeconomic structure of the household, employment, income, health, empowerment, social assistance, migration, physical safety, and inclusion without feeling embarrassed dimensions, with three indicators for each dimension, for a total of 27 indicators. Subsequently, the deprivation line for these indicators (Annex 1) and whether women were deprived in each indicator were determined and a deprivation matrix was created using Equations 1,2 and 3. Due to the fact that the number of indicators in each dimension is equal, the indicators were equally weighted and women who experienced deprivation in at least 9 of the 27 indicators were considered to be "poor". In other words, while the poverty line was determined as $\mathrm{k}=9$ in the study, women who were deprived in at least 9 of the 27 indicators (C, equation 3 ) were accepted as "poor" according to the method discussed, which is consistent with the study of Alkire and Foster (2011a) in terms of the number of indicators/poverty line. Accordingly, the headcount ratio (H-Equation 4) and the average deprivation rate (A-Equation 5) were calculated based on the data of women identified as poor for each district and the overall sample, and the adjusted headcount ratio (multidimensional poverty index) $\left(\mathrm{M}_{0}\right.$-Equation 6) was calculated by multiplying these two values. The high index value, in other words, its proximity to 1 , indicates that poverty is higher (Alkire \& Foster, 2011a). In other words, policymakers were presented with specific policy suggestions for women, and the areas where priority should be given to reducing women's poverty were proposed by determining the dimensions in which women experience intense deprivation according to the data obtained.

As a result of the measurements, it was determined that 223 of the 400 women in the sample experienced deprivation in at least 9 indicators. In other words, more than half of the 400 women living in Antalya can be considered as poor. Out of these 223 poor women, the number of women deprived in 9 indicators is 49 , while the number of women deprived in 10 
indicators is 46. Even though the number of poor women decreases as the number of indicators deprived increases, the number of indicators with the highest deprivation rises up to 19 . In other words, while 5 women are deprived in 17 indicators at the same time, the number of women deprived in 18 indicators is 2 and the number of women deprived in 19 indicators is 1 , respectively. Given that there were 27 indicators included in the study, it is possible to say that this woman, who is deprived of 19 indicators, is the poorest individual in the sample. On the other hand, the average number of indicators in which women experienced deprivation is 11.5 , and the multidimensional poverty approach attributes importance to this value along with the number of individuals experiencing deprivation. The average deprivation rate (A), which is the value of deprivation per indicator experienced by the poor, stands out here and carries the analysis to a different dimension compared to the one-dimensional approaches.

Following these findings, the headcount ratio $(\mathrm{H})$ was determined to be 0.557 , while the average deprivation rate (A) was 0.426 , and the adjusted headcount ratio, namely the multidimensional poverty index $\left(\mathrm{M}_{0}\right)$, was 0.2374 . As previously stated, the closer the index value is to one, the greater/more severe the poverty. In addition to these findings, it is seen that the analysis results differ from region to region. For example, according to the data set of 80 women in each district, it can be said that the district with the highest number of poor women is Döşemealtı (50 women), while the district with the lowest number of poor women is Muratpaşa (41 women). The number of women who live in Kepez, Konyaaltı and Serik and suffer from deprivation in at least 9 indicators, is 43,43 and 46, respectively. Considering the district-based headcount ratio and average deprivation rate values, the multidimensional poverty rate of each district can be obtained. Döşemealtı district is again negatively differentiated among all districts in terms of women's poverty. In other words, the adjusted headcount ratio, namely the multidimensional poverty index value, is at the highest level in the district of Döşemealt1. Furthermore, while the $\mathrm{M}_{0}$ value of Döşemealtı is 0.271 , this value is about 0.035 points above the Antalya city-wide value (0.237). In other words, women living in Döşemealtı can be considered the most disadvantaged in terms of poverty.

However, considering the multidimensional poverty index, it can be said that women who are positively differentiated between all districts reside in Konyaalt1, which is also supported by the index value of Konyaaltı district, which is 0.217 (Table 3). As highlighted before, the relatively low value of the mentioned index means that poverty is less felt among women living in Konyaalt district. The multidimensional poverty index values obtained in other districts are 0.247 in Serik and 0.227 in Kepez and Muratpaşa. Based on these findings, it can be said that women living in Serik are struggling with high poverty rates, although not as much as women living in Döşemealtı. In short, Döşemealtı and Serik are the districts where women's poverty is highest, which can shed light on policymakers in terms of regional priority.

$4 \quad H=\frac{223}{400}=0.557$ (11) $\quad A=\frac{\left(\frac{2570}{223}\right)}{27}=0.426 \quad(12) \quad M_{0}=H \times A=0.557 \times 0.426=0.237$ 
Table 2

Multidimensional Poverty Index Values of Employed Women in Antalya and Selected Districts

\begin{tabular}{|c|c|c|c|c|c|c|}
\hline & ANTALYA & DÖŞEMEALTI & KEPEZ & KONYAALTI & SERIK & MURATPAŞA \\
\hline$q$ (poor) & 223 & 50 & 43 & 43 & 46 & 41 \\
\hline n (sample) & 400 & 80 & 80 & 80 & 80 & 80 \\
\hline $\begin{array}{l}\text { Number of } \\
\text { Poverty Line } \\
\text { Indicators }\end{array}$ & 9 & 9 & 9 & 9 & 9 & 9 \\
\hline $\begin{array}{l}\text { Number of } \\
\text { Indicators }\end{array}$ & 27 & 27 & 27 & 27 & 27 & 27 \\
\hline $\begin{array}{l}\text { Average Po- } \\
\text { verty Rate }\end{array}$ & 11.5 & 11.7 & 11.4 & 10.9 & 11.6 & 12.0 \\
\hline H & 0.557 & 0.625 & 0.538 & 0.538 & 0.575 & 0.513 \\
\hline $\mathbf{A}$ & 0.426 & 0.434 & 0.423 & 0.403 & 0.430 & 0.444 \\
\hline$M_{0}=H \times A$ & 0.237 & 0.271 & 0.227 & 0.217 & 0.247 & 0.227 \\
\hline
\end{tabular}

Table 3

Districts with the Highest and Lowest Multidimensional Poverty Index Values

\begin{tabular}{lcc}
\hline & HIGHEST & LOWEST \\
\hline H & 0.625 (Döşemealtı) & 0.513 (Muratpaşa) \\
A & 0.444 (Muratpaşa) & 0.403 (Konyaaltı) \\
Mo & $\mathbf{0 . 2 7 1 ~ ( D o ̈ s ̧ e m e a l t ı ) ~}$ & $\mathbf{0 . 2 1 7}$ (Konyaaltı) \\
\hline
\end{tabular}

In the study, at the stage of obtaining the multidimensional poverty index, it is possible to determine which woman experiences deprivation in which indicator by using the deprivation matrix. Thus, Table 4 reflects where the deprivation in question is concentrated in terms of dimensions and indicators, while the findings can be considered as a clue to policy priorities both for poor women and for the overall sample. As emphasized above, 223 women in the sample are poor according to the multidimensional approach. The dimension of income is the one in which these women suffer the most deprivation. On the other hand, about $60 \%$ of these poor women are paid below the minimum wage, more than $80 \%$ live in debt and have no savings. Similarly, given the entire Antalya sample, approximately one out of every 2 women earns below the minimum wage level. Furthermore, 3 out of every 4 women in Antalya are indebted and continue their lives without any savings. Another dimension in which poor women experience intense deprivation is the employment dimension, where 138 of the 223 poor working women do not have a formal employment contract. In line with this finding, nearly $90 \%$ of the same poor women work more than 8 hours/day. It should also be emphasized that only $34(15.2 \%)$ of the women who were found to be poor stated that they were subjected to psychological or physical pressure at the workplace. This reflects that a significant majority of poor women are satisfied with the environment in which they work, even though they earn an income below the minimum wage and do not have formal employment contracts. However, perhaps the most important point that should not be overlooked here is that 34 women are not just statistics, and they are subjected to pressure at work in one way or another so that harm to the physical or mental integrity of even 1 woman can result in irreparable consequen- 
ces. The ratio of poor women who feel that their physical safety is/will be in danger not only at the workplace, but also in their household or the environment they live in is not small at all. In other words, the ratio of poor women who think that they may encounter violence in the next 1 year is $54.3 \%$. In the recent past, the number of poor women whose safety was compromised due to theft was 40, while the number of those who stated that they had experienced an incident that resulted in violence/injury in the last 5 years was 17 . As in the workplace, no violence or pressure that is experienced in the household or in the immediate environment and could damage human dignity is acceptable. Therefore, it is essential to ensure the physical and mental integrity in the working life, home or close environment of the individual, whether male or female, where policymakers and practitioners have great responsibilities within the framework of reconsidering the laws and implementing the existing ones. 17 poor women who are exposed to violence, which seems to be part of statistical data within these lines, have to be protected by deterrent laws and public power/ingenuity, and moreover, must be empowered to never face such problems again.

Another dimension in which the most deprivation is experienced compared to other dimensions addressed specifically for poor women in Antalya is the dimension of social assistance. The women included in the study were required to be married and employed, which means that the woman brings income to the household whether her husband is working or not. Analyzes made related to the dimension of social assistance indicate that approximately $92 \%$ of women who are found to be poor experience difficulties in making a living. On the other hand, while the poor women who reported that they need social assistance accounted for $43 \%$ of the sample of 223 people, only $8 \%$ of them can access unrequited social assistance from the state, private sector or their relatives. In the meantime, $62.8 \%$ of these poor people stated that they migrated for economic reasons at least once in their lives, and $36.8 \%$ of them stated that there was no change in their living conditions although they migrated. In addition, 1 out of every 5 women identified as poor are planning to migrate from Antalya in the near future.

Of the 223 poor women in the Antalya sample, 91 stated that their health status was not good, and 60 of them stated that their health issues were affecting their lives negatively. About half of the same group feel that they are being treated with prejudice and excluded. On the other hand, $6.3 \%$ of poor women state that they feel/will feel ashamed of their poverty. Furthermore, 19 poor women do not have washing machines and dishwashers (both), while $60 \%$ of them do not own a computer. About 1 in every 3 poor women do not have access to the internet.

Along with poor women, similar results are encountered when the entire Antalya sample is evaluated. As mentioned above, approximately half of the women in Antalya earn an income below the minimum wage, and approximately $75 \%$ of them have debts. In addition, 
the ratio of women who do not have any savings is around $70 \%$. In addition to the income dimension, a brief summary of the dimensions and indicators in which intense deprivation is experienced throughout Antalya, is as follows; $53.5 \%$ of working women do not have an employment contract, $72.8 \%$ work more than 8 hours a day, $80 \%$ have financial difficulties, more than 50\% migrate for economic reasons, nearly $40 \%$ do not feel free and are dependent on others (husband, father, mother, etc.) when making personal decisions, and approximately one in every three women reports being treated with prejudice and excluded. The ratio of women who have been exposed to violence in the last 5 years is around 5\%, while the ratio of women who think that they will encounter violence in the next 1 year exceeds $50 \%$, which is quite a high rate. This result corresponds to the fact that physical safety is an increasingly high-risk factor for women, both from the household (spouse) and the social environment. These findings indicate that approximately half of the women in Antalya do not have a computer of their own, $20 \%$ do not have access to the internet, and 1 in 20 women do not have both washing machine and dishwasher.

Table 4

Deprivation of Employed Women in Antalya in Dimensions and Indicators

\begin{tabular}{|c|c|c|c|c|c|c|c|}
\hline & & POOR (223 & Vomen) & & SAMPLE (400 & Vomen) & \\
\hline $\begin{array}{l}\text { DIMENSI- } \\
\text { ONS }\end{array}$ & INDICATORS & $\begin{array}{l}\text { NUMBER } \\
\text { OF WO- } \\
\text { MEN DEP- } \\
\text { RIVED }\end{array}$ & TOTAL & $\begin{array}{l}\text { PLACE OF } \\
\text { THE DEP- } \\
\text { RIVATION }\end{array}$ & $\begin{array}{l}\text { NUMBER OF } \\
\text { WOMEN DEP- } \\
\text { RIVED }\end{array}$ & TOTAL & $\begin{array}{l}\text { PLACE } \\
\text { OF THE } \\
\text { DEPRIVA- } \\
\text { TION }\end{array}$ \\
\hline \multirow{3}{*}{$\begin{array}{l}\text { SOCIO- } \\
\text { ECO- } \\
\text { NOMIC } \\
\text { STRUCTU- } \\
\text { RE }\end{array}$} & $\begin{array}{l}\text { White appliances } \\
\text { (washing machi- } \\
\text { ne + dishwasher) }\end{array}$ & $19(8.5 \%)$ & \multirow[t]{3}{*}{214} & \multirow[t]{3}{*}{$8^{\text {th }}$} & $22(5.5 \%)$ & \multirow[t]{3}{*}{277} & \multirow[t]{3}{*}{$9^{\text {th }}$} \\
\hline & Computer & $134(60.1 \%)$ & & & $\mathbf{1 7 7}(44.3 \%)$ & & \\
\hline & Internet & $61(27.4 \%)$ & & & $78(19.5 \%)$ & & \\
\hline \multirow{3}{*}{$\begin{array}{l}\text { EMPLOY- } \\
\text { MENT }\end{array}$} & $\begin{array}{l}\text { Employment } \\
\text { contract }\end{array}$ & $138(61.9 \%)$ & \multirow{3}{*}{364} & \multirow{3}{*}{$2^{\text {nd }}$} & $214(53.5 \%)$ & \multirow{3}{*}{556} & \multirow{3}{*}{$2^{\text {nd }}$} \\
\hline & $\begin{array}{l}\text { Daily working } \\
\text { hours }\end{array}$ & $192(86.1 \%)$ & & & $291(72.8 \%)$ & & \\
\hline & $\begin{array}{l}\text { Psychological/ } \\
\text { physical pressure }\end{array}$ & $34(15.2 \%)$ & & & $51(12.8 \%)$ & & \\
\hline \multirow{3}{*}{ INCOME } & Net wage & $133(59.6 \%)$ & \multirow{3}{*}{506} & \multirow{3}{*}{1 st } & $186(46.5 \%)$ & \multirow{3}{*}{765} & \multirow{3}{*}{$1 \mathrm{st}$} \\
\hline & Debt & $\mathbf{1 8 5}(83.0 \%)$ & & & $297(74.3 \%)$ & & \\
\hline & Savings & $\mathbf{1 8 8}(84.3 \%)$ & & & $282(70.5 \%)$ & & \\
\hline \multirow{3}{*}{ HEALTH } & Health status & $91(40.8 \%)$ & \multirow{3}{*}{234} & \multirow{3}{*}{$6^{\text {th }}$} & $107(26.8 \%)$ & \multirow{3}{*}{284} & \multirow{3}{*}{$7^{\text {th }}$} \\
\hline & $\begin{array}{l}\text { Number of he- } \\
\text { alth problems }\end{array}$ & $\mathbf{8 3}(37.2 \%)$ & & & $106(26.5 \%)$ & & \\
\hline & $\begin{array}{l}\text { Effects of health } \\
\text { problems }\end{array}$ & $60(26.9 \%)$ & & & $71(17.8 \%)$ & & \\
\hline \multirow{3}{*}{$\begin{array}{l}\text { EMPO- } \\
\text { WERMENT }\end{array}$} & $\begin{array}{l}\text { Personal decision } \\
\text { control }\end{array}$ & $108(48.4 \%)$ & \multirow{3}{*}{268} & \multirow{3}{*}{$5^{\text {th }}$} & $157(39.3 \%)$ & \multirow{3}{*}{389} & \multirow{3}{*}{$5^{\text {th }}$} \\
\hline & $\begin{array}{l}\text { Reasons not to } \\
\text { work }\end{array}$ & $41(18.4 \%)$ & & & $60(15.0 \%)$ & & \\
\hline & Feeling free & $119(53.4 \%)$ & & & $172(43.0 \%)$ & & \\
\hline
\end{tabular}




\begin{tabular}{|c|c|c|c|c|c|c|c|}
\hline \multirow{3}{*}{$\begin{array}{l}\text { SOCIAL } \\
\text { ASSISTAN- } \\
\text { CE }\end{array}$} & $\begin{array}{l}\text { Financial diffi- } \\
\text { culty }\end{array}$ & $205(91.9 \%)$ & \multirow{3}{*}{319} & \multirow{3}{*}{$3^{\text {rd }}$} & $316(79.0 \%)$ & \multirow{3}{*}{451} & \multirow{3}{*}{$3^{\text {rd }}$} \\
\hline & $\begin{array}{l}\text { Need for social } \\
\text { assistance }\end{array}$ & $96(43.0 \%)$ & & & $113(28.3 \%)$ & & \\
\hline & $\begin{array}{l}\text { Receiving social } \\
\text { aid }\end{array}$ & $18(8.1 \%)$ & & & $22(5.5 \%)$ & & \\
\hline \multirow{3}{*}{$\begin{array}{l}\text { MIGRATI- } \\
\text { ON }\end{array}$} & Migration & $140(62.8 \%)$ & \multirow{3}{*}{271} & \multirow{3}{*}{$4^{\text {th }}$} & $214(53.5 \%)$ & \multirow{3}{*}{391} & \multirow{3}{*}{$4^{\text {th }}$} \\
\hline & $\begin{array}{l}\text { Changes in living } \\
\text { conditions as a } \\
\text { result of migra- } \\
\text { tion }\end{array}$ & 82 (36.8\%) & & & $111(27.8 \%)$ & & \\
\hline & $\begin{array}{l}\text { Migration plans } \\
\text { in the future }\end{array}$ & $49(22.0 \%)$ & & & $66(16.5 \%)$ & & \\
\hline \multirow{3}{*}{$\begin{array}{l}\text { PHYSICAL } \\
\text { SAFETY }\end{array}$} & Theft & $40(17.9 \%)$ & \multirow[b]{3}{*}{178} & \multirow[b]{3}{*}{$9^{\text {th }}$} & $58(14.5 \%)$ & \multirow[b]{3}{*}{279} & \multirow[b]{3}{*}{$8^{\text {th }}$} \\
\hline & $\begin{array}{l}\text { Physical violence } \\
\text { / injury }\end{array}$ & $17(7.6 \%)$ & & & $\mathbf{1 8}(4.5 \%)$ & & \\
\hline & $\begin{array}{l}\text { Possibility of } \\
\text { exposure to } \\
\text { violence within } \\
1 \text { year }\end{array}$ & $121(54.3 \%)$ & & & $203(50.8 \%)$ & & \\
\hline \multirow{3}{*}{$\begin{array}{l}\text { INCLU- } \\
\text { SION } \\
\text { WITHOUT } \\
\text { FEELING } \\
\text { EMBAR- } \\
\text { RASSED }\end{array}$} & $\begin{array}{l}\text { Feeling embar- } \\
\text { rassed due to } \\
\text { poverty }\end{array}$ & $14(6.3 \%)$ & \multirow{3}{*}{216} & \multirow{3}{*}{ 7th } & $22(5.5 \%)$ & \multirow{3}{*}{312} & \multirow{3}{*}{$6^{\text {th }}$} \\
\hline & $\begin{array}{l}\text { Being treated } \\
\text { with prejudice }\end{array}$ & 99 (44.4\%) & & & $141(35.3 \%)$ & & \\
\hline & Feeling excluded & $103(46.2 \%)$ & & & $149(37.3 \%)$ & & \\
\hline
\end{tabular}

As a result, the study's findings indicate that a vast majority of women living in Antalya are poor according to the multidimensional poverty approach. This is supported by the fact that the city's headcount ratio is 0.557 and the multidimensional poverty index is 0.237 . Furthermore, it is possible to conclude that the indexes of Döşemealtı women are higher than those of the entire city, meaning that they are poorer. Similarly, women living in Serik experience poverty at a higher rate than the Antalya average. Those who live in Kepez, Konyaalt, and Muratpaşa, on the other hand, are in a better situation in terms of multidimensional poverty. As a result, it could be proposed that the districts of Döşemealtı and Serik be given policy priority in order to reduce women's poverty to the lowest levels possible. Increasing women's initial income (purchasing power), especially in these districts, and allowing them to make more savings will make them stronger. Furthermore, prioritizing changes in job contracts and working hours at the stage of gaining more income could have beneficial effects in favor of women. Furthermore, as women's educational levels rise, their status at work will shift from wage earner to employer. This will help to inspire them and enable them to engage more actively in decision-making processes at work and at home. Women who can stand more strongly on their feet will be able to extend their areas of freedom and increase their capacity to combat discrimination. This would also protect them from physical and psychological pressure as well as abuse in the home and at work. Equal opportunities for men and women in the home will be the secret to raising strong and happy generations, which will pave for social peace and development in the long term. 


\section{Conclusions}

In this study, the poverty of women in Antalya is assessed using socioeconomic indicators and the multidimensional measurement method (AF Approach), and policy recommendations are made based on the indicators that they are experiencing severe deprivation. In September 2020, a field study was conducted with 400 married and working women between the ages of 15 and 65 in five Antalya districts, including Döşemealtı, Kepez, Konyaaltı, Serik, and Muratpaşa, using a face-to-face survey method, and the data set obtained from it formed the basis of the study. The main goal in adopting the multidimensional measurement method rather than one-dimensional measurements focusing on income or consumption level is to shed light on the issues of women who face socioeconomic inequality while having an income above a certain threshold. The study focuses on 9 dimensions of poverty measurement. These dimensions can be listed as socioeconomic structure, employment, income, health, empowerment, social assistance, migration, physical safety, and inclusion without feeling embarrassed. In addition, each dimension is represented by 3 indicators and women who experience deprivation in at least 9 of 27 indicators in total are considered to be poor. As a result of the study, it is seen that 223 of the 400 women in the Antalya sample are poor according to the multidimensional measurement method and the headcount ratio is 0.557 , while the average deprivation rate is 0,426 , and the multidimensional poverty index 0.237 .

As a result, in the case of Antalya (with the priority of Döşemealtı and Serik districts), the most important steps to be taken in order to strengthen the struggle of women against poverty is to ensure their physical and mental integrity and review the legal framework for eliminating economic and physical violence. Both policymakers and practitioners have a great responsibility to take deterrent measures so that women will be able to feel safe in their homes, close environments and workplaces. Furthermore, increasing educational attainment, especially among women, would socially empower women. In other words, having a population density of universities and higher degrees, especially with a focus on women, would shift their status at work as well as their participation in the labor market, facilitating women's access to better conditions as their economic freedom expands. Women will be able to engage in household decisions and be empowered in a wide range of areas, including health, technical infrastructure, immigration, social assistance, and physical/mental safety, as their income, status in the workplace and socioeconomic class improve. Therefore, as previously mentioned, enhancing women's education, reducing and even eliminating discriminatory and marginalizing judgments, ensuring equality of opportunity in all fields, and fighting poverty are all essential measures to take. Conducting new studies to see how women's poverty (index values) has changed over time in Antalya would provide insight into the fight against women's poverty in the region and across the country. Furthermore, empirical analyses of the poverty in question and the factors that can be successful in combating it will provide an indication of the direction and magnitude of the potential effects and will again guide policymakers. 
Peer-review: Externally peer-reviewed.

Conflict of Interest: The author has no conflict of interest to declare.

Grant Support: This study has been prepared with the support of TUBITAK (Project ID: 119K804). I would like to thank TUBITAK for its financial support in the preparation of this study.

\section{References}

Açıkgöz, R. (2010). Kadın yoksulluğu üzerine bir inceleme. Yardım ve Dayanışma Dergisi, 1(2), 45-60. Retrieved from https:/www.acarindex.com/dosyalar/makale/acarindex-1423938558.pdf

Alkire, S. (2007). The Missing Dimensions of Poverty Data: Introduction to the Special Issue, Oxford Development Studies, 35(4), 347-359. http://dx.doi.org/10.1080/13600810701701863

Alkire, S., \& Foster, J. (2011a). Counting and multidimensional poverty measurement, Journal of Public Economics, 95(7), 476-487. http://dx.doi.org/10.1016/j.jpubeco.2010.11.006

Alkire, S., \& Foster, J. (2011b). Understandings and misunderstandings of multidimensional poverty measurement, The Journal Of Economic Inequality, 9(2), 289-314. http://dx.doi.org/10.1007/s10888-0119181-4

Alkire, S., \& Santos, M. E. (2014). Measuring acute poverty in the developing world: Robustness and scope of the multidimensional poverty index. World Development, 59, 251-274. http://dx.doi.org/10.1016/j. worlddev.2014.01.026

Alkire, S., \& Seth, S. (2013). Selecting a targeting method to identify BPL Households in India, Social Indicators Research, 112(2), 417-446. http://dx.doi.org/10.1007/s11205-013-0254-6

Arpacı, F. (2010). Yoksulluk ve kadın yoksulluğu [Poverty and woman poverty]., Üçüncü Sektör Kooperatifçilik, 45(4), 1-9. Retrieved from http://www.makalesistemi.com/panel/files/manuscript_files_publish/e6 1942b4897972dd6a60f8037db34c7c/3594bc96c1ff67859bcc16e16c51754b/1b67d842f870564.pdf

Bastos, A., Casaca, S.F, Nunes, F., \& Pereirinha, J. (2009). Women and poverty: A gender sensitive approach, The Journal Of Socio-Economics, 38(5), 764-778. http://dx.doi.org/10.1016/j.socec.2009.03.008

Batana, Y. M. (2013). Multidimensional measurement of poverty among women in Sub-Saharan Africa", Social Indicators Research, 111(2), 337-362. http://dx.doi.org/10.1007/s11205-013-0251-9

Bayır, M. (2018). Kadın yoksulluğunun sosyo-ekonomik önemi: Türkiye-Avrupa Birliği karşılaştırması [Socio-economic importance of the women poverty comparison between Turkey and European Union], (Master dissertation) Retrieved from: http://acikkaynak.bilecik.edu.tr/xmlui/handle/11552/483

Buvinic, M. (1997). Women in poverty: A new global underclass, Foreign Policy, 108, 38-53, http://dx.doi. org $/ 10.2307 / 1149088$

Büyükyörük, N. (2019). Kadınların yoksulluk deneyimlerinin temellendirilimiş kuram yaklaşımıyla analizi [An analysis of women's poverty experiences with the grounded theory approach] (Doctoral dissertation). Retrieved from: http://tez.sdu.edu.tr/Tezler/TS02975.pdf

Duyan Çamur, G. (2010). Yoksulluğun kadınlaşması: Altındağ örneği [Feminisation of poverty: An example of Altındag region of Ankara]. Aile ve Toplum, 11(6), 19-29. http://dx.doi.org/10.21560/spcd.54833

Ecevit, Y. (2003). Toplumsal cinsiyetle yoksulluk ilişkisi nasıl kurulabilir? Bu ilişki nassl çalışabilir? [How can a relationship between gender and poverty be established? How can this relationship work?]. Cumhuriyet Üniversitesi Tip Fakültesi Dergisi, 25(4), 83-88. 
Foster, J.E. (2007). A report on Mexican multidimensional poverty measurement, Oxford Poverty and Human Development Initiative Working Paper Series, 40, Retrieved from: https://ophi.org.uk/a-report-onmexican-multidimensional-poverty-measurement/

Foster, J., Greer, J., \& Thorbecke, E. (1984). A class of decomposable poverty measures, Econometrica, 52(3), 761-766. http://dx.doi.org/10.2307/1913475

Gerşil, G., (2015). Küresel boyutta yoksulluk ve kadın yoksulluğu [Poverty on a global scale and women poverty]. Yönetim ve Ekonomi Dergisi, 22(1), 165-187.

Goldberg, G.S., \& Kremen E. (1990). The feminization of poverty discovered in America. In G.S. Golberg \& E. Kremen (Eds.), The feminization of poverty: Only in America? New York, Greenwood Press.

Kardam, F., \& Yüksel, İ. (2004). Kadınların yoksulluğu yaşama biçimleri: Yapabilirlik ve yapabilirlikten yoksunluk [How women experience and cape with poverty: Capabilities and functionings], Nüfusbilim Dergisi, 26(1), 45-72. Retrieved from: https://dergipark.org.tr/tr/pub/nufusbilim/issue/22964/245731

Kartal, A., \& Zanbak, M. (2020). Kadın yoksulluğunun çok boyutlu analizi: Antalya alt bölgesi örneği [Multidimensional analysis of women poverty: The case of Antalya subregion]. Pamukkale Üniversitesi Sosyal Bilimler Enstitüsü Dergisi, 41, 294-315. http://dx.doi.org/10.30794/pausbed.650746

Krueger A.B., \& Schkade, D. A. (2008). The reliability of subjective well-being measures, Journal of Public Economy, 92(8-9), 1833-1845. http://dx.doi.org/10.1016/j.jpubeco.2007.12.015

Maduekwe, E. (2018). Women in agriculture: Application of Alkire-Foster method of counting multidimensional deprivation towards building a human recognition index for women in Malawi, 30th International Conference Of Agricultural Economists (pp. 1-39)., Vancouver, http://dx.doi.org/10.22004/ ag.econ. 276974

Moghadam, V. (2005), The feminization of poverty and women's human rights, SHS Papers in Women's Studies/Gender Research, 2(1), 28-36. Retrieved from: http://www.unesco.org/new/fileadmin/MULTIMEDIA/HQ/SHS/pdf/Feminization_of_Poverty.pdf

Pearce, D. (1978). The feminization of poverty: Woman, work and welfare, Urban and Social Change Review, 11(1), 28-36. Retrieved from: https://www.researchgate.net/publication/234759249_The_Feminization_of_Poverty_Women_Work_and_Welfare

Peterson, J. (1987). The feminization of poverty, Journal Of Economic Issues, 21(1), 329-337. http://dx.doi. org/10.1080/00213624.1987.11504613

Sen, A. (1999). Development as freedom. New York, NY: Knopf Publishers.

Sen, A. (1976). Poverty: An ordinal approach to measurement, Econometrica, 44(2), 219-231. http://dx.doi. org $/ 10.2307 / 1912718$

Şahin, E., \& Şahin, N.H. (2018). Kadın yoksulluğu ile mücadele yöntemleri [Women struggling with poverty methods]. Journal Of Current Researches On Health Sector, 8(2), 209-220. http://dx.doi.org/10.26579/ jocrehes_8.2.19

Şener, Ü. (2012). Kadın yoksulluğu [Women poverty]. Mülkiye Dergisi, 36(4), 51-67. Retrieved from: https://dergipark.org.tr/tr/pub/mulkiye/issue/1/7

TEPAV, (2009). Kadın yoksulluğu [Women poverty]. Türkiye Ekonomi Politikaları Araştırma Vakfı. Retrieved from: https://www.tepav.org.tr/upload/files/1271312994r5658.Kadin_Yoksullugu.pdf

Topgül, S. (2013). Türkiye'de yoksulluk ve yoksulluğun kadınlaşması [Poverty in Turkey and the feminization of poverty], Cumhuriyet Üniversitesi Iktisadi ve İdari Bilimler Dergisi, 14(1), 277-296. Retrieved from: https://kutuphane.dogus.edu.tr/mvt/pdf.php 
Townsend, P. (1979). Poverty in UK: A survey of household resources and standards of living, London, Penguin Books,

TurkStat, (2019, March 10). Adrese Dayalı Nüfus Kayıt Sitemi, Retrieved from https://biruni.tuik.gov.tr/ bolgeselistatistik/degiskenlerUzerindenSorgula.do?durum $=$ acKapa \&menuNo $=249 \&$ altMenuGoster $=1 \&$ secilenDegiskenListesi $=$

TÜAD, (2012). Sosyoekonomik statü ölçeği, [Socio economic status of turkey] Türkiye Araştırmacılar Derneği Sosyoekonomik Statü Revize Projesi Yayını, İstanbul. Retrieved from https://tuad.org.tr/upload/dosyalar/SES_Projesi.pdf

UNDP, (1995). Human development report, New York, Oxford University Press, Retrieved from http://hdr. undp.org/sites/default/files/reports/256/hdr_1995_en_complete_nostats.pdf

Wilson, J.B. (1987). Women and poverty: A demographic overview, Women and Health, 12(3), 21-40. http:// dx.doi.org/10.1300/J013v12n03_02

World Bank, (2000). World development report 2000/2001: Attacking poverty, New York. Oxford University Press. Retrieved from https://openknowledge.worldbank.org/handle/10986/11856

Wu, Y., \& Qi, Di. (2017). “A gender - based analysis of multidimensional poverty in China”. Asian Journal Of Women's Studies, 23(1), 66-88. http://dx.doi.org/10.1080/12259276.2017.1279886

Yalçın, Z. (2018). Kadın yoksulluğu [Women poverty]. (Master dissertation). Retrieved from: https://www. academia.edu/38553032/Kad\%C4\%B1n_Yoksullu\%C4\%9Fu_Zeki_Yal\%C3\%A7\%C4\%B1n_docx

Zanbak, M. (2014), Yetenekler yaklaşımı perspektifi ile yoksulluğun ölçülmesi: Yoksulluğun kayıp boyutları üzerine ampirik bir uygulama [Measuring poverty from the perspective of capabilities approach: an empirical analysis on missing dimensions of poverty] (Doctoral dissertation). Retrieved from: https://tez. yok.gov.tr/UlusalTezMerkezi/tezSorguSonucYeni.jsp 399540

Zanbak, M., \& Çağatay, S. (2013). "Yetenek" yaklaşımı temelinde yoksulluğun ölçülmesi: Mersin ve Erzurum illerinde yoksulluğun kayıp boyutları [Measurement of poverty on the basis of the "capability" approach: missing dimensions of poverty in the cities of Mersin and Erzurum]. Iktisat Issletme ve Finans, 28(327), 67-104. http://dx.doi.org/10.3848/iif.2013.327.3662 


\section{Annex 1: Deprivation Conditions Related to Dimensions and Indicators Used in the Multidimensional Poverty Measurement}

\begin{tabular}{ll}
\hline DIMENSIONS/INDICATORS & DEPRIVATION CONDITIONS \\
\hline INFORMATION ABOUT THE & S1.1. Do you have a washing machine and dishwasher (both) in your home? \\
PERSON AND THE SOCIOE- & Deprived if the answer is "No" \\
CONOMIC STRUCTURE OF & S1.2. Do you have your own computer (laptop or desktop)? \\
THE HOUSEHOLD & Deprived if the answer is "No" \\
White appliances (Washing mac- & S1.3. Do you have internet access in your home? \\
hine + Dishwasher) & Deprived if the answer is "No" \\
Computer Internet &
\end{tabular}

\section{EMPLOYMENT}

Employment contract

Daily working hours

Psychological, physical pressure
S2.1. Do you have an employment contract with your employer?

Deprived if the answers are one of the following: "No, I don't have a formal contract" "Yes, I have an unofficial contract" "No, I didn't know it had to be"

S2.2. How many hours do you work daily?

Deprived if "over 8 hours"

S2.3. Do you experience psychological and/or physical pressure in your workplace?

Deprived if the answer is one of the following: "So lightly", "Lightly", "Moderate", "Much", "Too Much"

S3.1. What is the net salary you earned from your main job last month?

\section{INCOME}

Net wage

Debt

Savings

\section{HEALTH}

Health status

Number of health problems

Effects of the health problems

\section{EMPOWERMENT}

Personal decision control Possible reasons for inability to work in the future

Feeling free

Deprived "if less than 2324.70 TL"

S3.2. Do you have any debt?

Deprived if the answer is "Yes"

S3.3. Do you have savings?

Deprived if the answer is "No"

S4.1. How would you describe your current health status?

Deprived if the answer is one of the following: "Very bad", "Bad", "Normal"

S4.2. Write down the total number of your health problems.

Deprived if the answers is not " 0 "

S4.3. How much do these health problems affect your daily routine?

Deprived if the answer is one of the following: "Too much", "Excessive", "Tolerable", "Little"

S5.1. To what extent do you feel you can control your personal decisions that affect your daily activities?

Deprived if the answer is one of the following: "I can't control any of my decisions", "I can control very little of my decisions", "I can control some of my decisions"

S5.2. Could you explain the possible reasons why you might work or not take part in any job in the future? Choose the one that suits you best.

Deprived if the answer is one of the following: "Zero control", "External pressure", "Obtaining approval"

S5.3. Which step do you see yourself on today? 1 dependent 6 independent

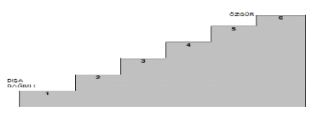

Deprived if the answer is one of the following: "1", "2", "3"

S6.1. Do you think your household is in financial difficulties?

SOCIAL ASSISTANCE

Financial difficulties

Need for social assistance

Receiving social aid
Deprived if the answer is one of the following: "So lightly", "Lightly", "Moderate", "Severe", "Very severe

S6.2. Do you think your household needs social assistance for the poor or needy? Deprived if the answer is "Yes"

S6.3. Did you receive any help other than debt from any institution or persons such as relatives, neighbors, philanthropists due to financial difficulties?

Deprived if the answer is "Yes" 


\section{MIGRATION}

Migration

Changes in living conditions as a result of migration

Migration plans in the future

S7.1. Have you ever migrated in your lifetime?

Deprived if the answer is "Yes"

S7.2. How have your living conditions changed after migration?

Deprived if the answer is one of the following: "Worsened", "Didn't change"

S7.3. Do you have any migration plans in the near future?

Deprived if the answer is one of the following: "Not decided", "Yes"

S8.1. Has someone trespassed in your home or flat in recent years and has stolen or attempted to steal anything that belongs to you?

Deprived if the answer is "Yes"

PHYSICAL SAFETY

Theft

Physical violence / injury

Possibility of exposure to violence

within 1 year

S8.2. Excluding the previous incidents, have you or any member of your family been shot at your home or outside with a firearm (knife, etc.), subjected to violence or beaten in the past 5 years? (kick, push, etc.)

Deprived if the answer is "Yes"

S8.3. What is the possibility of being a victim of one of the above-mentioned violence events within the following 12 months?

Deprived if the answer is one of the following: "Very likely" "Probably" "Low probability but may" "Very unlikely"

S9.1. I would be embarrassed if I was poor.

INCLUSION WITHOUT FEE- Deprived if the answer is one of the following: "I agree", "I have no idea"

\section{LING EMBARRASSED}

Feeling embarrassed due to poverty

Being treated with prejudice Feeling excluded
S9.2. Have you felt people approach you with prejudice during the last 3 months? Deprived if the answer is one of the following: "Always", "Sometimes", "Often", "A little"

S9.3. Do you feel excluded?

Deprived if the answer is one of the following: "Always", "Sometimes", "Often", "A little" 